\title{
Forum
}

\section{The Strasbourg Speeches}

\author{
Jerome Moran \\ Independent Scholar
}

Key words: Strasbourg Oaths, Roger Wright, Romance, Alcuin, Lingua Romana

[Readers of this article should be aware of the revisionist (in their time, certainly) and controversial views of Roger Wright (1982) about the relationship between Latin and Romance, the separation of Latin and Romance, and the dates he proposes for these and for the beginning of Medieval Latin as a newly constituted form of Latin ${ }^{1}$.]

Understandably, because of their importance for linguists, we hear a lot about the Strasbourg Oaths. We hear rather less about the pledges made at Strasbourg at the same time by the two armies, and even less about the two speeches made by the two kings, Louis and Charles. In fact, I doubt that most people who have heard of the Strasbourg Oaths are even aware of the Strasbourg speeches. They raise an interesting problem, which is the principal subject of this article. The most convenient way for teachers and students to access the text of the Strasbourg Oaths is to view the Wikipedia article on the 'Oaths of Strasbourg' at Oaths of Strasbourg - Wikipedia

(Wikipedia does have its uses, and I am not one of those who look down on it indiscriminately.) In fact, they need to have sight of the text of all the various pronouncements, and of the narrative in which they occur, if they are to follow the account of them that is given in this article. The Wikipedia article also gives the historical background and context of the meeting of the kings and their armies at which the pronouncements were made.

But what have the Strasbourg Oaths to do with students and teachers of Classics? If you were to ask this question of a teacher of Classics and a teacher of French (or of Medieval History, because of the content and context of the document), you might get the answer of 'everything' or 'nothing', depending on whether they regarded it as (possibly) the last extant document of a form of living Latin or the first extant document in French. There was a time when students of French (and of Medieval History), if not of Classics, were expected to be aware of this document and of its relationship to Latin (a time when students of French (and Medieval History) were expected to have a knowledge of Latin). For linguistic and historical reasons, it is important for us to have another look at the document and some of the issues it raises. Too much emphasis has been put on the oaths rather than on the (only) account that we have of the other pronouncements, especially the speeches, that were made at

Author of correspondence: Jerome Moran, E-mail: jeromemoran@hotmail.com Cite this article: Moran $\mathrm{j}$ (2021). The Strasbourg Speeches. The Journal of Classics Teaching 22, 50-54. https://doi.org/10.1017/10.1017/S2058631021000076
Strasbourg in 842 . And if we are saying goodbye to living Latin, we and our students should be aware of when it died. Those of our students who are aware of the continuing existence of Latin after 842 in the form of Medieval and Neo-Latin are probably not aware of when it became a 'dead' language - if it ever did.

I was prompted to write this article on reading the brief account that James Clackson gives of the Strasbourg Oaths on p.268 and pp.300-301 of The Blackwell History Of The Latin Language (Clackson, 2010). (I may say that I would not have written it at all if I had not been able to view a facsimile of the document itself, including the pledges and speeches.) The fact that more is not generally available to Classicists is probably because, as Clackson says, 'full discussion of this text belongs in a history of French, rather than a history of Latin'. Perhaps so, but the earliest French, like other Romance languages, came mainly from the latest (living) Latin. Surely this is of importance to Classicists?

The author of the narrative that contains the Strasbourg Oaths (our only source) is Nithard, a $9^{\text {th }}$ century Frankish historian. He is said to have died in 844 , so shortly after the event he narrates. The only manuscript that contains his narrative (apart from a $15^{\text {th }}$ century copy) dates to around 1000. (You can view images of parts of it in the Wikipedia article.) It is possible therefore that the manuscript does not accord, in language or content, with some of the details of what Nithard wrote.

I am assuming the following:

(a) The 'natural' language of Louis ('The German'), or the part of the Frankish kingdom he ruled over (much of present Germany), is what is described in Nithard's account as teudisca lingua (TL), an early form of German. The 'natural' language of Charles ('The Bald'), or of the part of the Frankish kingdom he ruled over (present France, more or less), is what is described as romana lingua (RL). (Their older brother Lothair controlled the central part of the Frankish kingdom.)

(b) Louis and Charles switched languages for their oaths but not for their speeches. The armies did not switch languages for their pledges either ${ }^{2}$.

(c) A distinction is being drawn between a form of Latin and a nonLatin vernacular, unless romana lingua should be regarded as a form of independent Romance, (proto-) French, not as a form of Latin - however it was regarded at the time. Teudisca lingua was certainly not a form of Latin or a Romance vernacular ${ }^{3}$. 
According to Nithard's account the proceedings went as follows:

Speech 1 was delivered by Louis in TL

Speech 2 was delivered by Charles in RL

(on the languages of the speeches see below)

Oath 1 was delivered by Louis in RL

Oath 2 was delivered by Charles in TL

Pledge I was delivered by the army of Charles in RL

Pledge 2 was delivered by the army of Louis in TL

(Note that 'Ludher' is Lothair (see above), not Louis (who is the speaker of the oath). The mistake appears to be Clackson's, since 'Louis' is one of the glossed words, not one of the words in Ewert's 'translation'. Lothair is of course the subject of the complaint that accounts for most of the two speeches.)

To turn now to the actual account given by Nithard of the events at Strasbourg in 842. Clackson writes:

However, it should be emphasized that the lingua romana also encompasses Latin as well as what we think of as early French. In Nithard's account of the Strasbourg allegiance he explicitly describes as lingua romana both the speech in Latin made by the brothers before their pledge and the short text of the oaths sworn by the kings and their armies (Clackson, 2010, p. 268).

This is confused and confusing, as I shall show. According to Nithard's account, there were two speeches (by Louis and Charles), two oaths (again by Louis and Charles) and two pledges (by the army of Charles and the army of Louis), in the order I have given them above. The oaths and the pledges are given in what purport to be the original words, which is possible if Nithard was writing shortly after the event. But what of the speeches? Immediately before the speech of Louis begins we find in Nithard's account 'Ac sic ante sacramentum circumfusam plebem, alter teudisca, alter romana lingua, allocuti sunt'. Immediately after the end of the speech of Louis we find 'Cumque Karolus haec eadem verba romana lingua perorasset'. Does this not suggest that the speech of Louis was actually delivered in teudisca lingua and the speech of Charles in romana lingua? Only the speech of Louis is given by Nithard (the content of both speeches was more or less identical, hence 'haec eadem verba'). The speech is presented by Nithard in what is undoubtedly Latin (whatever we make of Charles' 'romana lingua', if it was anything like Louis' oath and the pledge of Charles's army). Clackson says that 'he explicitly describes as lingua romana both the speech made by the brothers before their pledge and the short text of the oath sworn by the kings and their armies.' (This seems to confuse the pledges of the armies and the oaths of the kings.) But he (Nithard) appears to distinguish the languages of the speeches made by the brothers, as I have suggested. And the oaths and the pledges of the armies are also distinguished, only the oath of Louis and the pledge of the army of Charles being described as delivered in romana lingua. Where does the Latin of the speech of Louis come from? Are we supposed to think that the speeches of the brothers were given both in the Latin we are presented with and in teudisca lingua (by Louis) and romana lingua (by Charles)? So, in the 'standard' Latin of the day and the very much 'non-standard' Latin of romana lingua, if that is what it was (see notes 1, 2 and 5)? But is it possible that the Latin of the speech of Louis is in fact a 'translation' of the original words of the speech in teudisca lingua? The Latin of the speech is remarkably similar to the Latin of Nithard in the rest of his account. There is no indication that the speeches were made twice by both kings, once in formal Latin and then again in teudisca lingua and romana lingua. There were two speeches, as identical speeches (identical in content, that is) were given in both languages so that everyone present could understand them. The near-identical oaths and pledges would have to have been given by each side even if they had been given in the same language, precisely because they were oaths and pledges. However, one speech, given by either king, would have been sufficient had the two sides shared a common language.

I think the explanation for presenting the speech of Louis in formal Latin may be as follows (I am not aware that this explanation has already been given elsewhere - but then nobody was ever the first to say anything, as the unoriginal saying goes):

The purpose of the brothers' oaths and their armies' pledges was to protect each other against their older brother, Lothair. Some explanation of why this was necessary was called for. The opening speeches of the brothers provide this, containing as they do their complaints against Lothair. The speeches were almost identical in content (as were the oaths and pledges that followed) so it was only necessary for Nithard to give one version. It was known that Louis, as the older brother, spoke first. But Louis spoke teudisca lingua. How many of Nithard's readers would have been able to understand a lengthy speech (lengthy relative to the oaths and pledges) delivered in German (a lingua barbara after all)? So Nithard presented it in the lingua franca of formal Latin, the conventional medium for historical prose, rather than in the language that was actually used to deliver it ${ }^{4}$. Oaths and pledges were such that the ipsissima verba of them should be given, where possible. And each oath and pledge were given in romana lingua as well as teudisca lingua, the former being more accessible to Nithard's readers, whether a form of Latin or not.

Nithard might have had access to written records of the oaths and pledges, but not of the speeches (there may not have been one, especially in German, even if everything had been scripted beforehand $)^{5}$. The speeches were for the historical record, whereas the oaths (and perhaps the pledges too) were paralegal documents. The Council of Tours a few years previously (813) had sanctioned the use of German ('thiotisca') and rustica romana lingua in churches, rather than Alcuin's reformed Latin, and these were the two languages of the oaths and pledges. And oaths and pledges had a religious dimension that an explanatory preamble did not ${ }^{6}$.

As for Alcuin's reformed Latin, there is a further consideration, one that might explain why the speeches were not in fact delivered in (formal) Latin, as one might expect - or the oaths and pledges too, come to think of it. By 842 formal written Latin was coming to be pronounced in accordance with the recent (within the past 50 years) reforms of Alcuin, therefore (more) phonetically and 'correctly', as Classical Latin was thought to have been pronounced. In the so-called 'Dark Age(s)', if not earlier, before the time of Alcuin formal Latin had been pronounced (and written) 'incorrectly', in varying regional forms of incorrectness, but - and this is the point - in forms that were able to be understood in the different regions. Once Alcuin's reforms took hold, the uniform, reformed, 'received' Latin was not able to be understood in any region. Louis and Charles were the sons of Louis ('The Pious'), more importantly grandsons of Charlemagne, who had authorised the reforms. They were applied initially to liturgical texts. Unless they were still confined to such texts in 842 , Louis and Charles could have delivered their speeches in the new kind of Latin, as 
might have been expected on such an occasion. But most of the people gathered might not have been familiar with the new pronunciation at this time and therefore would not have been able to understand the speeches. As it was, because the same speech was given in the two different vernaculars, everyone could understand them. And, as mentioned above, this was exactly the proposed solution of the Council of Tours a few years earlier, when the new, reformed pronunciation was evidently causing problems of understanding for the congregations.

Whether we should regard the ordinary, informal spoken Latin of the Dark Ages and earlier as being forms of Romance, and Alcuin's reformed Latin as the true beginning of Medieval Latin, is another matter. Nearly 40 years ago the Latinist and Romance scholar Roger Wright in his controversial book Late Latin and Early Romance in Spain and Carolingian France (Wright, 1982) began to question the accepted relationship between Latin and Romance ${ }^{7}$.

He continued to do so, expanding and elaborating his theory in subsequent books and articles, notably in the book (a collection of his articles) A Sociophilological Study of Late Latin (Wright, 2003). He argued that from about 400 until about 800 Latin and Romance were in fact the same thing, or forms of the same thing, that what we call Romance was originally the ordinary spoken form of 'Late Latin'. Romance did not begin to be something separate from Latin until the pronunciation of written Latin was altered, and therefore the oral delivery of it to audiences unfamiliar with it, especially church congregations, as explained in the previous paragraph. According to Wright, this was a new form of Latin that was unintelligible to the people used to the older Latin. Romance eventually ceased to be perceived as (a form of) Latin (while Latin came to be regarded as no longer a spoken language for everyday purposes) and continued life separately from Latin as Romance, developing its own languages, eventually with its own written vernaculars ${ }^{8}$. This new form of Latin was Medieval Latin, invented about 800 to represent the new pronunciation. Medieval Latin therefore was not an evolved form of (written) Latin that had existed continuously (and survived miraculously through the Dark Age) from about 500. Alcuin did not reform Classical or Late Latin so much as create a new form of Latin. This theory, or parts of it, has attracted many supporters, though the early dating of Romance and the late dating of Medieval Latin continue to trouble scholars. Also, we know very little about the written Latin that was produced (very little is extant) in the bridging centuries between late antiquity and the Carolingian Renaissance to make an informed comparison with it and what went before and what came after it.

Other questions occur to one about Wright's theory. What was the everyday spoken Latin of the ordinary person like before it came to be Late Latin/Romance c. 400 ? Was it more like the everyday spoken Latin of the educated elite who could read and write Classical Latin or a derivative of it? But before 400 standard written Latin had to be learned as if it were a second language, which suggests that contemporary spoken Latin (of the educated elite at least) was very different from educated written Latin at that date. What was so distinctive about the new form of ordinary, everyday spoken Latin that we should regard it as the same form of Latin that hundreds of years later eventually ceased to be Latin and became a collection of other languages? Not simply that it was spoken rather than written, obviously. Presumably because later Romance had many features that were outcomes of changes that occurred in Late Latin and not earlier. But early (early according to the traditional dating) Romance came from Latin generally, not just from everyday spoken Latin ('Vulgar Latin'), as many people still suppose.
What happened to formal written Latin during the period from about 400 to 800 ? Very few existing literary texts were read or copied. Very few new texts were written. This was because there were few opportunities to learn formal written Latin (it was of course learned by native speakers of Latin as if it were a second language). There were probably many fewer grammar schools in the whole of continental Europe than there are in the UK today (about 160). Certain texts, especially texts that were needed, mainly liturgical texts, continued to be read aloud by those who could read to those who could not read. Few of the readers knew how the texts should be pronounced 'correctly', and the 'correct' pronunciation was so different from the contemporary pronunciation that audiences would not have understood it in any case. The texts were therefore read aloud in the contemporary regional pronunciations, heavily influenced by ordinary spoken Latin. As well as being pronounced incorrectly, any new written texts came increasingly to contain errors, i.e. non-Classical usages, of orthography, morphology and syntax. This was essentially the situation that confronted Alcuin. Alcuin's response was to reform or reconstitute Latin. The people's response (not a deliberate, concerted one, of course) was to abandon Latin in the form in which it had now become, with momentous consequences: the birth of a host of new languages and the death of Latin as the first language of native speakers - but thankfully not the death of Latin, the report of whose death has been greatly exaggerated. Latin from now on was learned by everyone as it is today - as a second language.

('Romance' is of course the term conventionally used not for Latin at all but for those European languages that evolved from Latin - and much later than 400 . The term 'proto-Romance' is, however, conventionally used for the hypothetical, reconstructed forms of the very late Latin that are thought to be the forms of Latin from which the earliest forms of Romance evolved - much later than 400. Nobody before Wright had supposed that Romance was a form of Latin, spoken as early as 400, or that Medieval Latin was an invented, as opposed to an evolved, form of Latin, as late as 800 . The conventional view is that ordinary spoken Latin in and before 400 and until the emergence of Romance centuries later was 'Vulgar Latin', now more usually termed 'vernacular' or 'non-standard' Latin,)

However, as I understand it, applying Wright's theory to Nithard's account leads us to conclude that what we are presented with is written Medieval Latin, Romance French and Old German. This is in fact the received view of the languages of the document. And the theory does not in itself help us to understand (a) why the speeches are presented in formal (Medieval) Latin if they were delivered in French and German, and (b) why the speeches, oaths and pledges were not delivered in formal Latin in the first place. I would like to think that my analysis and interpretation of the document does provide answers to both of these questions.

\section{Notes}

1 Lest 'revisionist' be misinterpreted here, see the explanation of the term in the link: https://contingentmagazine.org/2019/08/08/mailbag-august-8-2019/ (accessed 10/10/2020).

2 They were able to switch languages for the oaths because the oaths were very brief and written up beforehand. The oaths were either read aloud or memorised. The much longer speeches, I argue, were delivered in their own languages, as were the pledges of the armies. The oaths were made to people of a different language, and for that reason were made in that language. Why did this not happen in the case of the pledges made by the two armies? (Such pledges were unusual.) The pledges were actually addressed to both kings: a warning to their own king, an assurance to the other king. The armies were in effect acting as 
guarantors for their king's oath (highly unusual, one supposes). Strictly speaking, I suppose that each pledge should have been made in both languages, but this would have presented logistical difficulties. What form did it take? Was the pledge orated by the whole contingent (how many were there on each side?) or by the leader(s) only? Was it read aloud (how many of them could read? How many copies were needed?) or memorised?

3 Perhaps Latin was not used at all then at the gathering in Strasbourg in 842. Is the distinction to be made that of a Romance (i.e. Latin-based, but not Latin) vernacular and a non-Romance vernacular? Many people who do not accept Wright's view about the much earlier dating of Romance regard the romana lingua as presented by Nithard as a very early form of Romance, proto-French, rather than as a (very late) form of spoken Latin. But, as I have said, we cannot be sure that our manuscript of 150 years later does not contain features of later Romance that were not in Nithard's account. In the versions he gives us there are certainly several Romance features; but there are also features associated with non-standard Latin. This is why the precise language used has been disputed. My own view is that it is best to regard the language as transitional between Latin and Romance, rather than to assign it unqualifiedly to one or the other.

I am surprised how confidently some scholars can determine when one language turns into another, or when one form or period of a language turns into a different one. When did Latin become Italian? When did Anglo-Saxon become English? When did Celtic become Welsh? When did the Northumbrian dialect of Old English become Lowlands Scots? Just how many languages have there been that have turned into other languages, if that is what happened? How many languages are there like Greek that have never turned into some other language and are still alive to tell the(ir) story? But then we can't really say what a language is.

4 The Strasbourg Oaths appear in Nithard's historical work De dissensionibus filiorum Ludovici Pii. And if he did not have access to the original speech Nithard might have had difficulty in reconstructing a lengthy piece of Old High German, though there were some of the Latin-speaking elite who were competent in it, even if they did not advertise the fact.

5 The language of the Germanic-speaking peoples who came to take over the lands of the Roman Empire after 500 did not seriously challenge the position of Latin, thanks largely to the obduracy of Christianity. In fact, they capitulated to Latin as the Normans were to do with French, if not quite so quickly. By about 400 Latin had become more or less the sole language in most of the provinces of the western half of the empire (but see the end of this note). The regional indigenous languages had disappeared. Britain, however, was an exception. Latin in Britain never became the sole language as it did in other provinces. As a learned language it was confined to the urban areas and to the Romano-British elite. If it became a first language at all rather than a learned second language, it was confined to a small minority and was never imposed on the population by Rome (Rome's usual 'language policy', or rather the absence of one). As far as the adoption of Latin and Romanitas was concerned, the people 'Romanised themselves', as Brunt put it (see Clackson (2010, p. 231)). Latin of course was the language of the army (though no doubt some flexibility had to be allowed), the law and the administration of the province. The first language of the soldiers who came from provinces outside Britain was increasingly Latin, and they possibly knew no other language in many cases. Britain was a small, outermost island province, not all of which Rome could control in any case. It had tin and grain but little else that Rome wanted - apart from taxes, soldiers and slaves.

It has been suggested that the Germanic languages already had a presence in parts of the east and south of England in the fifth century when the larger scale movements from the continent to Britain began. Most of the Germanic peoples were Christian too, which made it easier for them to defer (eventually) to the official language of Christianity, especially as they came to defer to Roman Christianity itself in place of their own Arian brand.

Germanic languages were spoken also by those peoples who came to settle in the lands of the former Roman Empire in continental Europe. These tend to get overlooked, though an early form of German was the first written vernacular in Europe after Irish and English - in fact the first if we count the early bible (fourth century) in Gothic of Ulfilas.

The Latin-speaking part of the population of the former empire was always much more numerous, and the Germanic-speaking part dwindled over time and conceded to Latin (the unassailable language of a common faith), but it was to forms of Latin that were developing into what was to become the separate Romance languages. Only in England did a Germanic language come to be the main, almost the sole language, Also, in the eighth century Arabic began to replace Latin in many parts of the former empire, inside and outside Europe. But by then the days of Latin as a lingua franca of everyday speech were numbered everywhere. Only the high form of Latin was to survive (after 800 in a reconstituted form, if Wright is correct), but as a 'cultural artefact' (Clackson, 2010) of an educated elite, which it still is.

A list of languages and language groups that we know existed in lands of the former Roman empire at its greatest extent (so Irish is excluded, as are languages used in Scotland), during the whole or part of the period from about 500 to 900 (from a notional date of the end of the Roman empire until a notional date after which there were no native speakers of Latin, except perhaps in Italy), would comprise the following: Latin, Greek, Romance, Basque, Germanic, Celtic (England and Wales), Armenian, proto-Albanian, Slavonic, Coptic, Libyan, (possibly) Punic, Arabic, Aramaic (including Syriac). Most of the languages on the list had been in use in the empire too for some time. There were no doubt others, including ones in the same regions as those on the list, mainly oral with small communities of speakers that we do not know of since they have not left any written record. Throughout the whole of this period Latin (in the later part of it Romance as languages separate from Latin) and Greek accounted for most of the users by far, and the primacy of Latin and Greek accounted for the disappearance of most of the ones that did not survive. But it was still a multilingual world, not a monolingual (Latin only) or bilingual (Latin and Greek), as we Classicists are sometimes inclined to picture it.

6 If romana lingua (with the addition of rustica) used in 813 in Canon 17 of the Council of Tours also denotes what we call proto-French (it could not have had that meaning for those who used the expression in 813), then we have an exact parallel with the Strasbourg Oaths: a Romance vernacular and a non-Romance vernacular (lingua thiotisca). But this does not preclude the possibility that what was called lingua romana was regarded as a form of Latin by those who used the expression, including Nithard. Indeed, it is claimed that the words Romana and Latina were used as synonyms when applied to language (see Adams, 2003) and the term Romania had been used of lands of the Roman empire since the fourth century (see Curtius, 2013). Who at the time -813 , 842,1000 - would have been aware of a change of language as opposed to change in language? When exactly people realised that this form of Latin was no longer Latin but some other language, I leave to those who think that they can determine such things.

So how are we to understand the term 'lingua romana' as used by Nithard? He gives us two examples of what he describes as lingua romana: the oath of Louis (in the language of the west Franks) and the pledge of the army of Charles (in their own language, the language of the west Franks). He says that the speech of Charles was also given in romana lingua, but he does not reproduce this. If romana when used of a language still meant the same as latina in Nithard's day, this might suggest that Nithard at least thought that these pronouncements were in some form of Latin. (We should probably understand the expression rustica romana lingua used in 813 as 'rustic Latin' to distinguish it from the new, polished Latin recently introduced by Alcuin, a form of Latin popularly known as 'Vulgar Latin' and better known now as 'non-standard' or 'sub-elite' Latin.) It is possible then that Nithard uses 'romana lingua' to distinguish Latin from German, not to distinguish sub-elite Latin from elite Latin.

However Adams (2003, p.197), in the article cited says that in the ninth century 'lingua romana' came to denote the sub-elite Latin from which the Romance languages evolved, hence the term 'Romance', or in Latin 'Romanica', which came to replace 'Romana'. The term 'lingua latina' was then reserved for elite Latin. So perhaps this is the meaning that we should attach to Nithard's use of the term. If so, the question then to be asked is whether Nithard thought that lingua romana was a form of Latin or (what we call) Romance. He does not describe it as 'Francisca', a term that by the date of the manuscript at least could probably be used to describe the language of the west Franks, Charles's people, rather than the German of the east Franks (see Clackson, 2010, pp. 266-7). If he did regard it as Latin, he cannot have failed to notice how different it was from his own Latin. It seems to me that we cannot be sure in what sense Nithard used the term, whether in its original general sense or in the special sense it may have acquired during his lifetime. More importantly, we ourselves are still not able to say whether it is the latest extant document in Latin or the earliest extant example of French.

When we use the word 'Latin' we usually have in mind elite Latin. But there are contexts in which we use it to mean Latin generally, and contexts in which 
we use it specifically of sub-elite Latin. And for us the English expressions 'the language of the Romans' and 'the Latin language' are synonymous; at least they have the same referent if not the same meaning, to make the philosopher Frege's useful distinction. Perhaps the usage of Latin speakers was similar. But any distinctions between forms of Latin would have been as nothing compared with the distinction between Latin (and Greek) and lingua barbara - any language other than Latin and Greek.

7 For a list of reviews for and against the views advanced in the book, and an outline of them by Francis Cairns much like that given here, go to https://francis-cairns.co.uk/ARCA081st.html\#ReviewsARCA8 (accessed 12/10/2020).

8 It should be noted, however, that for centuries later people in Italy still regarded Italian as a form of Latin rather than as a Romance vernacular that had evolved from Latin but was no longer Latin. This was the subject of Dante's De Vulgari Eloquentia, (in Latin), and the supposed diglossia made up of the lower register of 'volgare' (perceived by Dante as the superior form of Latin) and the higher register of 'grammatica' (perceived by Dante, not unreasonably perhaps, as an artificial construct of grammarians). One should bear in mind that Italy historically had a special relationship with Latin, one that encouraged this idiosyncratic view of the language. No other Romance vernacular was perceived of as Latin.

\section{References}

Adams, J. (2003). Romanitas and the Latin Language. Classical Quarterly, 53, 1, 195.

Clackson, J. (2010). The Blackwell History of the Latin Language. Oxford: Wiley-Blackwell.

Curtius, E. (2013). European Literature and the Latin Middle Ages. Princeton: Princeton University Press.

Wright, R. (1982). Late Latin and Early Romance in Spain and Carologinian France. Prenton: Francis Cairns (Publications) Ltd.

Wright, R. (2003). A Sociophilological Study of Late Latin. Utrecht: Brepols, NV. 